\title{
The comparison of the occurrence of the beneficial insects from Carabidae and Syrphidae families on a mix of flowering plants at two localities of Poland
}

\section{Porównanie występowania owadów pożytecznych z rodzin Carabidae i Syrphidae na mieszance kwitnących roślin w dwóch miejscowościach Polski}

\author{
Michał Hurej ${ }^{1 *}$, Jacek Twardowski ${ }^{1}$, Janusz Nowacki ${ }^{2}$, Paweł Sienkiewicz $^{2}$, \\ Paweł Trzciński ${ }^{2}$, Witold Łykowski
}

\section{Summary}

The aim of the study was a comparison of species composition and abundance of two insect families, i.e. ground beetles, Carabidae and hoverflies, Syrphidae, occurring on a mix of flowering plants at the two localities in western part of Poland. The studies were conducted in Jarosławiec (Wielkopolska province) and Pągów (Opole province), on the experimental fields belonging to BASF Polska Sp. z o.o., in 2012-2013. Pitfall traps were used for collecting Carabidae while entomological nets as well as yellow traps were used for collecting Syrphidae ecological analyses of ground beetles and hoverflies assemblages showed significant differences between the two compared localities, in particular qualitative evaluation.

Key words: mixture of flowering plants; biodiversity; Carabidae; Syrphidae

\section{Streszczenie}

Celem badań było porównanie składu gatunkowego i liczebności dwóch rodzin owadów, tj. chrząszczy Carabidae oraz muchówek Syrphidae w mieszance kwitnących roślin, w dwóch miejscowościach zachodniej Polski. Badania prowadzono w Jarosławcu (województwo wielkopolskie) i w Pągowie (województwo opolskie), na polach doświadczalnych należących do firmy BASF Polska Sp. z o.o. w latach 2012-2013. Do odłowów Carabidae stosowano pułapki Barbera, natomiast Syrphidae odławiano za pomocą czerpaka entomologicznego i żółtych pułapek Moerickego. W charakterystyce ekologicznej zgrupowań biegaczowatych oraz bzygowatych wykazano znaczne różnice między obiema porównywanymi miejscowościami, zwłaszcza pod względem jakościowym.

Słowa kluczowe: mieszanka kwitnących roślin; bioróżnorodność; Carabidae; Syrphidae

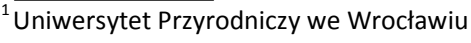
Katedra Ochrony Roślin

Plac Grunwaldzki 24A, 50-363 Wrocław

*corresponding author: michal.hurej@up.wroc.pl

${ }^{2}$ Uniwersytet Przyrodniczy w Poznaniu

Katedra Entomologii i Ochrony Środowiska

Kolegium Zembala

Dąbrowskiego 159, 60-594 Poznań

${ }^{3}$ BASF Polska Sp. z o.o.

Al. Jerozolimskie 154, 02-326 Warszawa
} 


\section{Wstęp / Introduction}

Mieszanka kwitnących roślin wysiewana w okolicy pól uprawnych zaliczana jest do istotnych elementów infrastruktury ekologicznej. Głównym celem takiego zabiegu jest zwiększenie bioróżnorodności roślinnej w agroekosystemach. Wraz ze wzrostem liczby gatunków roślin W środowisku wzrasta różnorodność gatunkowa fauny pożytecznej. Właściwie dobrane komponenty mieszanki są atrakcyjne dla różnych grup pożytecznych stawonogów, zarówno wrogów naturalnych szkodników, jak i zapylaczy. $\mathrm{W}$ badaniach przeprowadzonych w naszym kraju wykazano, że sztuczne miedze obsiane mieszanką złożoną z gorczycy białej (Sinapis alba L.), facelii błękitnej (Phacelia tanacetifolia Benth.) oraz kolendry siewnej (Coriandrum sativum L.) przywabiają liczne owady drapieżne, szczególnie Coccinellidae oraz Syrphidae (Hurej i wsp. 1998; Twardowski 2002; Twardowski i wsp. 2006). W badaniach cytowanych autorów, pozytywną reakcję na wysiew mieszanki odnotowano również w przypadku stawonogów epigeicznych, tj. chrząszczy $\mathrm{z}$ rodziny biegaczowatych (Carabidae), kusakowatych (Staphylinidae) i pajęczaków (Arachnida). W różnych krajach europejskich stosuje się z powodzeniem mieszanki składające się z od trzech do kilkudziesięciu gatunków roślin. Mogą to być zarówno rośliny uprawne (obok wcześniej wymienionych również np. koniczyna, gryka, słonecznik) lub też inne, obficie kwitnące rośliny zielne (np. chaber bławatek, rumianek pospolity, mak polny) (Carreck i Wiliams 1997; Balmer i wsp. 2013; Ditner i wsp. 2013). Problematyka wpływu zwiększonego zróżnicowania roślinnego w agrocenozach na liczebność fitofagów oraz ich wrogów naturalnych była i jest przedmiotem wielu projektów badawczych na całym świecie (Altieri i Letourneau 1982; Altieri; 1999; Gurr i wsp. 2004).

Celem badań było porównanie składu gatunkowego i liczebności dwóch rodzin owadów, tj. naziemnych chrząszczy Carabidae oraz odwiedzających kwiaty muchówek Syrphidae w mieszance kwitnących roślin w dwóch miejscowościach zachodniej Polski.

\section{Materiały i metody / Materials and methods}

Badania prowadzono w dwóch miejscowościach: Jarosławcu (województwo wielkopolskie) i Pągowie (województwo opolskie), na polach doświadczalnych należących do firmy BASF Polska Sp. z o.o. w latach 2012-2013. Odległość między miejscowościami wynosi około $150 \mathrm{~km} \mathrm{w}$ linii prostej. Mieszankę roślin wysiewano na powierzchni 1 ha, a w jej skład wchodziło 18 (2012) i 17 gatunków (2013) (tab. 1). W celu wykonania analizy botanicznej roślin w mieszance, losowo przy pomocy ramki $1 \mathrm{~m}^{2}$ wyznaczano 4 powierzchnie. Skład gatunkowy roślin w mieszance określano po wschodach, dwa tygodnie później oraz miesiąc po ostatniej obserwacji. Ustalono również stopień ilościowości według skali Braun-Blanqueta.

Tabela 1. Skład gatunkowy i liczebność roślin w mieszance, w Jarosławcu i Pągowie, w 2013 roku (średnio/m²) Table 1. Species composition and abundance of plants in a mix, in Jarosławiec and Pągów, in $2013\left(\mathrm{mean} / \mathrm{m}^{2}\right)$

\begin{tabular}{|c|c|c|c|c|c|}
\hline $\begin{array}{l}\text { Lp. } \\
\text { No. }\end{array}$ & Gatunek - Species & $\begin{array}{c}12.06 \\
\text { Jarosławiec }\end{array}$ & $\begin{array}{l}13.06 \\
\text { Pągów }\end{array}$ & $\begin{array}{c}2.07 \\
\text { Jarosławiec }\end{array}$ & $\begin{array}{c}1.07 \\
\text { Pągów }\end{array}$ \\
\hline 1 & facelia błękitna - Phacelia tanacetifolia Benth. & 22 & 30 & 16,5 & 27,8 \\
\hline 2 & koper ogrodowy - Anethum graveolens L. & 11 & 16,5 & 11,8 & 8,3 \\
\hline 3 & len zwyczajny - Linum usitatissimum L. & 8,5 & 8,8 & 3,5 & 5,5 \\
\hline 4 & nagietek lekarski-Calendula officinalis L. & 4 & 9,5 & 7,8 & 3 \\
\hline 5 & gryka zwyczajna - Fagopyrum esculentum Moench & 11 & 3,3 & 5,8 & 4 \\
\hline 6 & lucerna nerkowata-Medicago lupulina L. & 1,5 & 2,8 & 5,8 & 13,5 \\
\hline 7 & ślaz okółkowy - Malva verticillata $\mathrm{L}$. & 8,8 & - & 6,5 & 3 \\
\hline 8 & ogórecznik lekarski - Borago officinalis L. & 4 & 1 & 2,3 & 2,8 \\
\hline 9 & chaber bławatek-Centaurea cyanus L. & 3,5 & - & 4,5 & 2 \\
\hline 10 & lnicznik siewny - Camelina sativa Crantz & 1 & - & 4,3 & 4,5 \\
\hline 11 & złocień polny - Chrysanthemum segetum L. & - & 6,8 & - & 1,8 \\
\hline 12 & kolendra siewna - Coriandrum sativum $\mathrm{L}$. & - & 1,8 & 0,8 & 1,3 \\
\hline 13 & słonecznik zwyczajny - Helianthus annuus L. & 1,3 & 0,3 & 0,8 & 0,8 \\
\hline 14 & złocień zapoznany - Leucanthemum ircutianum DC & - & 2,5 & 0 & - \\
\hline 15 & czarnuszka siewna - Nigella sativa $\mathrm{L}$. & - & - & 0,5 & - \\
\hline 16 & mak polny-Papaver rhoeas L. & - & - & - & - \\
\hline 17 & nostrzyk lekarski-Melilotus officinalis (L.) & - & - & - & - \\
\hline \multicolumn{2}{|c|}{ Suma - Total } & 76,5 & 83,0 & 70,5 & 78,0 \\
\hline \multicolumn{2}{|c|}{$\begin{array}{l}\text { Liczba stwierdzonych gatunków } \\
\text { Number of identified species }\end{array}$} & 11 & 11 & 13 & 13 \\
\hline
\end{tabular}


Carabidae odławiano do 4 pułapek glebowych Barbera. Pułapki umieszczono w ziemi, równo z jej powierzchnią, w odległości 20 metrów jedna od drugiej, w jednym rzędzie, w środkowej części plantacji, na której uprawiano mieszankę. Pułapki stanowiły plastikowe kubki, o pojemności 0,51 i średnicy $9 \mathrm{~cm}$. Wypełniano je niewielką ilością glikolu etylenowego (stężenie 100\%) w celu konserwacji oraz uśmiercania wpadających do nich stawonogów. Nad każdą pułapką znajdował się plastikowy, przezroczysty daszek dla ochrony przed opadami atmosferycznymi. Odłowione stawonogi wybierano w odstępach 2-tygodniowych i przechowywano w pojemnikach z 70\% alkoholem etylowym.

Syrphidae odławiano dwiema metodami: za pomocą czerpaka entomologicznego oraz za pomocą naczyń żółtych. Czerpakowanie wykonywano czerpakiem o średnicy $40 \mathrm{~cm}$. Za każdym razem wykonywano 4 próby wzdłuż transektu $2 \times$ po 100 metrów, przecinającego się w środkowej części powierzchni badawczych. Za jedną próbę przyjmowano 25 uderzeń czerpakiem. Próby pobierano 2 razy $w$ miesiącu. Odłowiony materiał entomologiczny przekładano do woreczka, a następnie umieszczano $\mathrm{w}$ pojemniku $\mathrm{z}$ octanem etylowym w celu zatrucia odłowionych owadów. Pozyskany materiał przechowywano $\mathrm{w}$ pojemnikach wypełnionych $70 \%$ alkoholem etylowym. W przypadku odłowów Syrphidae do naczyń żółtych, na polu mieszanki umieszczono na stojakach 4 pułapki o średnicy $16 \mathrm{~cm}$, wysokości $7,5 \mathrm{~cm}$ i rozmieszczano w odległości 20 metrów jedna od drugiej, w jednym rzędzie w środkowej części plantacji. Wypełniano je wodą z dodatkiem środka zmniejszającego napięcie powierzchniowe. W czasie wysokich temperatur uzupełniano wyparowującą wodę. Pułapki w trakcie doświadczenia utrzymywano na wysokości wierzchołków roślin. Odłowiony materiał wybierano 2 razy w tygodniu i przechowywano w pojemnikach wypełnionych $70 \%$ alkoholem etylowym.

Jakościową i ilościową charakterystykę ekologiczna zgrupowań Carabidae oraz Syrphidae przedstawiono na podstawie liczebności ogólnej, liczebności gatunków, udziału procentowego gatunków, wskaźnika bogactwa gatunkowego Shannona-Wienera oraz porównano zgrupo- wania w kategoriach jakościowych współczynnikiem podobieństwa gatunkowego Sørensena.

\section{Wyniki i dyskusja / Results and discussion}

\section{Mieszanka kwitnących roślin}

Z uwagi na bardzo podobne wyniki dotyczące składu gatunkowego mieszanki w obu latach, w tabeli 1. przedstawiono dane uzyskane w 2013 roku. W czasie pierwszej analizy wykonanej na początku drugiej dekady czerwca, w obu miejscowościach, tj. Jarosławcu i Pągowie, odnotowano 11 gatunków roślin na 17 wysianych. Do najliczniejszych należały: facelia błękitna, koper ogrodowy i len zwyczajny. Dodatkowo w Jarosławcu, w znacznym nasileniu występowały: gryka zwyczajna i ślaz okółkowy, natomiast w Pągowie nagietek lekarski i złocień polny. Na początku lipca, w analizach przeprowadzonych w obu miejscowościach, wykazano po 13 gatunków roślin w mieszance. Również w tym terminie najliczniejszymi były rośliny facelii oraz kopru. W Jarosławcu na badanej powierzchni liczniej występowały też nagietek lekarski i ślaz okółkowy, natomiast w Pągowie w znacznym nasileniu stwierdzono lucernę nerkowatą.

W 2013 roku w Pągowie, w obu terminach badań największy procent pokrycia powierzchni gleby w mieszance zaobserwowano w przypadku facelii błękitnej, odpowiednio $23 \% \mathrm{w}$ pierwszym terminie i $45 \% \mathrm{w}$ drugim terminie (rys. 1). Znacznie mniejszą powierzchnię zajmował słonecznik zwyczajny. W pierwszym terminie roślina ta pokrywała powierzchnię plantacji nieco powyżej 5\%. Przybliżony stopień pokrycia odnotowano również w przypadku ogórecznika lekarskiego oraz lucerny nerkowatej. Pozostałe stwierdzone na plantacji gatunki roślin, z uwagi na małe rozmiary, zajmowały mniej niż 5\% analizowanej powierzchni (pokrycie nieznaczne) lub występowały sporadycznie (pokrycie znikome). W 2013 roku w podobny sposób kształtowało się pokrycie powierzchni plantacji mieszanki w Jarosławcu.

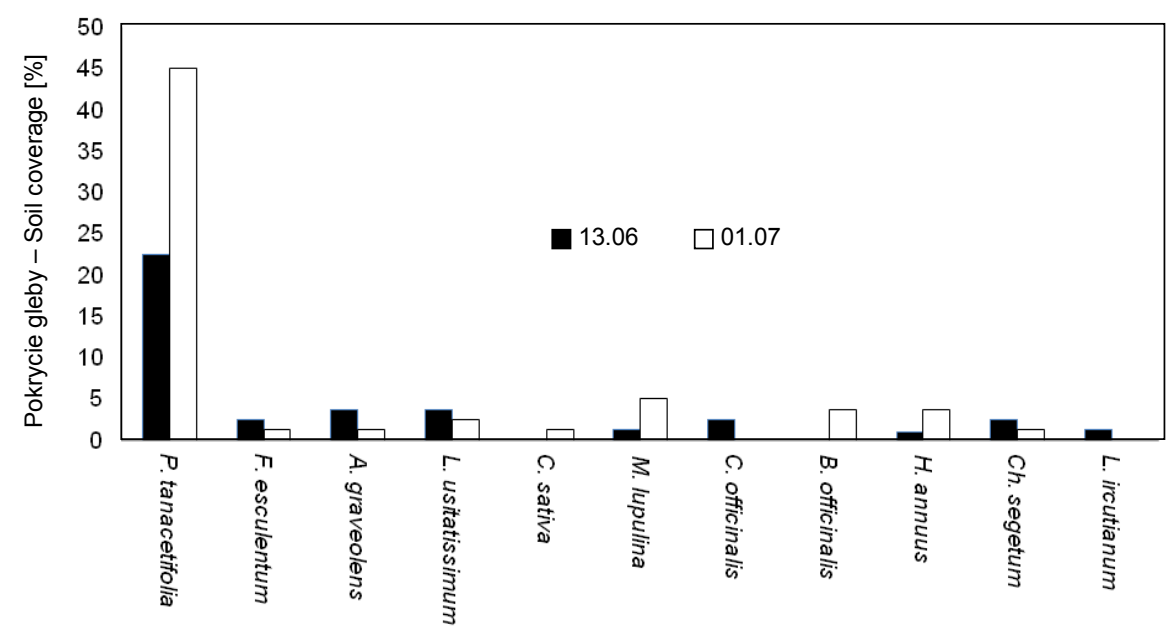

Rys. 1. Procent pokrycia powierzchni gleby przez poszczególne gatunki roślin (Pągów, 2013)

Fig. 1. Percentage of soil coverage by individual plant species (Pągów, 2013) 


\section{Charakterystyka ekologiczna zgrupowań Carabidae}

W tabeli 2. zamieszczono wykaz wszystkich gatunków Carabidae występujących w mieszance kwitnących roślin, oddzielnie dla każdego roku i dwóch porównywanych miejscowości. Łącznie, w latach 2012-2013 stwierdzono 64 gatunki tych owadów (46 w Jarosławcu i 45 w Pągowie). Ogółem, w ciągu dwóch lat badań w Jarosławcu odnotowano 2500 chrząszczy z rodziny Carabidae, natomiast w Pągowie 3755. W 2012 roku liczebność biegaczowatych odłowionych do pułapek Barbera w Pągowie była znacznie wyższa (2619 chrząszczy) niż w Jarosławcu (1131 chrząszczy). W drugim roku badań odnotowano odwrotną sytuację, tj. więcej omawianych owadów stwierdzono w Jarosławcu (1369 osobników), niż w Pągowie (1136 osobników). Zdecydowanym dominantem w obu miejscowościach i obu latach był Harpalus rufipes, gatunek hemizoofagiczny, odżywiający się pokarmem mieszanym, pospolicie występujący w różnych biotopach naszego kraju. W pierwszym roku badań udział procentowy tego gatunku był wyższy w Pągowie (46\%) w porównaniu do Jarosławca $(27,8 \%)$. W 2013 roku udział $H$. rufipes również był zdecydowanie wyższy w Pągowie $(75,8 \%)$ niż w drugiej miejscowości $(48,1 \%)$. Mniej licznie występował drapieżny Pterostichus melanarius. W 2012 roku w Pąowie oznaczono 42,8\% osobników tego gatunku wśród biegaczowatych, natomiast w Jarosławcu 11,4\%. P. melanarius w tej miejscowości był trzecim pod względem liczebności wykazanych gatunków. W 2013 roku udział $P$. melanarius w Pągowie wynosił 4,7\%, natomiast w Jarosławcu tylko 1,9\%. Odnotowano ponadto tylko trzy gatunki, których liczebność przekraczała 10\% w zgrupowaniach. Były to zoofagiczne gatunki odławiane w Jarosławcu: Poecilus lepidus (15,2\%, 2012 rok), Dolichus halensis $(10,2 \%, 2012$ rok) oraz Bembidion quadrimaculatum $(10,4 \%, 2013$ rok).

Tabela 2. Skład gatunkowy i liczebność Carabidae odławianych w dwóch miejscowościach, w latach 2012-2013

Table 2. The species composition and number of Carabidae caught at two localities in 2012-2013

\begin{tabular}{|c|c|c|c|c|c|c|c|c|}
\hline \multirow{3}{*}{$\begin{array}{l}\text { Gatunek } \\
\text { Species }\end{array}$} & \multicolumn{4}{|c|}{2012} & \multicolumn{4}{|c|}{2013} \\
\hline & \multicolumn{2}{|c|}{ Jarosławiec } & \multicolumn{2}{|c|}{ Pągów } & \multicolumn{2}{|c|}{ Jarosławiec } & \multicolumn{2}{|c|}{ Pągów } \\
\hline & $\mathrm{N}$ & {$[\%]$} & $\mathrm{N}$ & {$[\%]$} & $\mathrm{N}$ & {$[\%]$} & $\mathrm{N}$ & {$[\%]$} \\
\hline 1 & 2 & 3 & 4 & 5 & 6 & 7 & 8 & 9 \\
\hline Harpalus rufipes (Deg.) & 314 & 27,8 & 1205 & 46,0 & 658 & 48,1 & 852 & 75,8 \\
\hline Pterostichus melanarius (Ill.) & 130 & 11,4 & 1124 & 42,8 & 26 & 1,9 & 52 & 4,7 \\
\hline P. lepidus (Leske) & 172 & 15,2 & - & - & 82 & 6,1 & - & - \\
\hline Dolichus halensis (Schall.) & 116 & 10,2 & 31 & 1,3 & 58 & 4,3 & 20 & 0,3 \\
\hline Bembidion quadrimaculatum (L.) & 16 & 1,4 & 8 & 0,3 & 143 & 10,4 & 67 & 5,9 \\
\hline B. properans Steph. & 50 & 4,4 & 6 & 0,2 & 83 & 6,2 & 3 & 0,3 \\
\hline Anchomenus dorsalis (Pont.) & 20 & 1,8 & 66 & 2,4 & 41 & 3,0 & 5 & 0,4 \\
\hline Poecilus cupreus (L.) & 37 & 3,3 & 7 & 0,2 & 27 & 2,0 & 29 & 2,8 \\
\hline Harpalus affinis (Schrk.) & 34 & 3,2 & 5 & 0,1 & 31 & 2,1 & 10 & 0,2 \\
\hline H. psittaceus (Fourc.) & 75 & 6,5 & - & - & - & - & - & - \\
\hline Amara bifrons (Gyll.) & 5 & 0,3 & - & - & 63 & 4,6 & - & - \\
\hline Pterostichus niger (Sch.) & - & - & 47 & 1,7 & 1 & 0,1 & 5 & 0,4 \\
\hline Calathus ambiguus (Payk.) & 7 & 0,5 & 7 & 0,2 & 29 & 2,1 & - & - \\
\hline Amara similata (Gyll.) & 25 & 2,2 & 3 & 0,1 & 10 & 0,7 & 2 & 0,2 \\
\hline Harpalus froelichii Sturm & 14 & 1,2 & - & - & 20 & 1,5 & 1 & 0,1 \\
\hline Calathus fuscipes (Gze.) & 2 & 0,2 & 22 & 0,8 & 6 & 0,4 & 1 & 0,1 \\
\hline C. erratus Sahlb. & 4 & 0,3 & 9 & 0,3 & 16 & 1,2 & - & - \\
\hline Poecilus versicolor (Sturm) & 22 & 2,2 & - & - & 3 & 0,2 & 3 & 0,3 \\
\hline Calathus melanocephalus (L.) & 11 & 1,1 & 10 & 0,4 & 4 & 0,3 & - & - \\
\hline Amara aulica (Panz.) & 1 & 0,1 & 17 & 0,6 & 1 & 0,1 & 3 & 0,3 \\
\hline Zabrus tenebrioides (Gze.) & 21 & 1,9 & - & - & - & - & - & - \\
\hline Trechus quadristriatus (Schr.) & - & - & 4 & 0,1 & - & - & 15 & 1,4 \\
\hline Anisodactylus binotatus (Fabr.) & 5 & 0,3 & 1 & 0,1 & - & - & 13 & 1,3 \\
\hline Loricera pilicornis (Fabr.) & 3 & 0,2 & 9 & 0,3 & 5 & 0,3 & 2 & - \\
\hline Amara aenea (Deg.) & 4 & 0,4 & 1 & 0,1 & 3 & 0,2 & 8 & 0,9 \\
\hline Pterostichus vernalis (Panz.) & - & - & 14 & 0,5 & - & - & - & - \\
\hline Calosoma auropunctatum (Herb.) & 1 & 0,1 & - & - & 12 & 0,9 & - & - \\
\hline
\end{tabular}




\begin{tabular}{|c|c|c|c|c|c|c|c|c|}
\hline 1 & 2 & 3 & 4 & 5 & 6 & 7 & 8 & 9 \\
\hline Amara consularis (Duft.) & 1 & 0,1 & - & - & - & - & 11 & 1,2 \\
\hline Poecilus punctulatus (Schall.) & 11 & 1,1 & - & - & 1 & 0,1 & - & - \\
\hline Harpalus tardus (Panz.) & 3 & 0,3 & - & - & 5 & 0,3 & 4 & 0,4 \\
\hline Bembidion andreae (Fabr.) & 4 & 0,3 & - & - & 7 & 0,4 & - & - \\
\hline Harpalus griseus (Panz.) & 4 & 0,3 & - & - & 4 & 0,3 & 3 & 0,3 \\
\hline Bembidion lampros (Herbst) & 2 & 0,2 & 1 & 0,1 & - & - & 7 & 0,7 \\
\hline Clivina fossor (L.) & - & - & - & - & 10 & 0,7 & - & - \\
\hline Bembidion tetracolum Say & 2 & 0,2 & - & - & 6 & 0,4 & - & - \\
\hline Amara eurynota (Panz.) & - & - & 4 & 0,1 & - & - & 4 & 0,4 \\
\hline Ophonus puncticollis (Payk.) & 1 & 0,1 & 2 & 0,1 & - & - & 2 & 0,2 \\
\hline Amara plebeja (Gyll.) & - & - & - & - & 4 & 0,3 & 1 & 0,1 \\
\hline A. ingenua (Duft.) & 4 & 0,3 & - & - & - & - & - & - \\
\hline Harpalus smaragdinus (Duft.) & 4 & 0,3 & - & - & - & - & - & - \\
\hline Microlestes minutulus (Gze.) & 1 & 0,1 & - & - & 3 & 0,2 & - & - \\
\hline Ophonus signaticornis (Duft.) & 1 & 0,1 & - & - & 3 & 0,2 & - & - \\
\hline Notiophilus biguttatus (Fabr.) & - & - & 1 & 0,1 & - & - & 3 & 0,3 \\
\hline Harpalus distinguendus (Duft.) & - & - & - & - & - & - & 4 & 0,4 \\
\hline Carabus ullrichi Germ. & - & - & 3 & 0,1 & - & - & - & - \\
\hline Stomis pumicatus (Panz.) & - & - & 1 & 0,1 & - & - & 2 & 0,2 \\
\hline Amara ovata (Fabr.) & - & - & - & - & 1 & 0,1 & 2 & 0,2 \\
\hline Carabus granulatus $\mathrm{L}$. & 1 & 0,1 & 1 & 0,1 & - & - & - & - \\
\hline Harpalus brevicollis Aud.-Serv. & - & - & 2 & 0,1 & - & - & - & - \\
\hline Notiophilus aquaticus (L.) & - & - & 2 & 0,1 & - & - & - & - \\
\hline Carabus nemoralis Müll. & 1 & 0,1 & - & - & - & - & - & - \\
\hline Synuchus vivalis (Ill.) & 1 & 0,1 & - & - & - & - & - & - \\
\hline Agonum fuliginosum (Panz.) & 1 & 0,1 & - & - & - & - & - & - \\
\hline Acupalpus dorsalis (Fabr.) & - & - & - & - & 1 & 0,1 & - & - \\
\hline A. meridianus (L.) & - & - & 1 & 0,1 & - & - & - & - \\
\hline Agonum viduum (Panz.) & - & - & 1 & 0,1 & - & - & - & - \\
\hline Amara apricaria (Payk.) & - & - & - & - & - & - & 1 & 0,1 \\
\hline Badister bullatus (Schr.) & - & - & 1 & 0,1 & - & - & - & - \\
\hline Broscus cephalotes (L.) & - & - & - & - & 1 & 0,1 & - & - \\
\hline Carabus cancellatus Ill. & - & - & - & - & - & - & 1 & 0,1 \\
\hline Harpalus azureus (Fabr.) & - & - & 1 & 0,1 & - & - & - & - \\
\hline H. latus (L.) & - & - & 1 & 0,1 & - & - & - & - \\
\hline Syntomus foveatus (Geoff.) & - & - & - & - & 1 & 0,1 & - & - \\
\hline Harpalus sp. & - & - & 1 & 0,1 & - & - & - & - \\
\hline Suma - Total & 1131 & 100,0 & 2619 & 100,0 & 1369 & 100,0 & 1136 & 100,0 \\
\hline
\end{tabular}

$\mathrm{N}$ - liczebność - number

W 2012 roku w mieszance kwitnących roślin w Jarosławcu oznaczono łącznie 40 gatunków Carabidae, natomiast w przypadku odłowów przeprowadzonych w Pąowie było ich 35 (tab. 3). W Jarosławcu wykazano również 20 gatunków biegaczowatych, które w omawianym roku pojawiły się tylko w tej miejscowości. W drugiej z analizowanych miejscowości takich gatunków stwierdzono 15. $\mathrm{W}$ materiale pochodzącym $\mathrm{z}$ obu lokalizacji odnotowano 20 gatunków wspólnych.
W drugim roku badań (2013), liczebność odłowionych gatunków biegaczowatych w mieszance, ponownie była większa w Jarosławcu (35), niż w Pągowie (31). Odpowiednio, w pierwszej $\mathrm{z}$ analizowanych miejscowości wykazano 14 gatunków występujących tylko w niej, natomiast w drugiej miejscowości takich gatunków było 10 . Łącznie, podobnie jak w roku poprzednim, oznaczono 21 gatunków Carabidae, występujących zarówno w jednej, jak i w drugiej lokalizacji. Wskaźnik bogactwa gatunko- 
Tabela 3. Charakterystyka ekologiczna zgrupowań Carabidae w dwóch miejscowościach, w latach 2012-2013

Table 3. Ecological characteristic of ground beetle assemblages at two localities in 2012-2013

\begin{tabular}{|c|c|c|c|c|}
\hline & \multicolumn{2}{|c|}{2012} & \multicolumn{2}{|c|}{2013} \\
\hline & Jarosławiec & Pągów & Jarosławiec & Pągów \\
\hline Suma Carabidae - Total of Carabidae & 1131 & 2619 & 1369 & 1136 \\
\hline Liczba gatunków - Number of species & 40 & 35 & 35 & 31 \\
\hline $\begin{array}{l}\text { Liczba gatunków wyłącznych } \\
\text { Number of separate species }\end{array}$ & 20 & 15 & 14 & 10 \\
\hline $\begin{array}{l}\text { Liczba gatunków wspólnych } \\
\text { Number of common species }\end{array}$ & \multicolumn{2}{|c|}{20} & \multicolumn{2}{|c|}{21} \\
\hline $\begin{array}{l}\text { Wskaźnik Shannona-Wienera } \\
\text { Shannon-Wiener index }\end{array}$ & 2,50 & 2,45 & 2,11 & 2,09 \\
\hline \multicolumn{5}{|c|}{ Współczynnik Sørensena - Sørensen’s index } \\
\hline Jarosławiec & - & 0,53 & - & 0,63 \\
\hline Pągów & 0,53 & - & 0,63 & - \\
\hline
\end{tabular}

wego Shannona-Wienera potwierdził nieznaczne różnice jakościowe między zgrupowaniami występującymi w badanych miejscowościach i tak w 2012 roku wskaźnik H' wynosił 2,50 w Jarosławcu i 2,45 w Pągowie i odpowiednio w 2013 roku 2,11 i 2,09.

W charakterystyce ekologicznej zgrupowań Carabidae stwierdzonych w obu badanych miejscowościach obliczony współczynnikiem podobieństwa jakościowego Sørensena wyniósł 0,53 w 2012 roku oraz 0,63 w 2013. Uzyskane wartości świadczą o istotnej różnicy w podobieństwie składu gatunkowego.

\section{Charakterystyka ekologiczna zgrupowań Syrphidae}

W tabeli 4. podano liczebność i skład gatunkowy muchówek z rodziny bzygowatych, odławianych na mieszance kwitnących roślin do czerpaka entomologicznego, oddzielnie dla każdej $\mathrm{z}$ miejscowości i każdego roku badań. Łącznie w dwóch latach badań, w Jarosławcu odłowiono 294 osobniki należące do rodziny Syrphidae, natomiast w Pągowie 356. W pierwszym roku prowadzenia doświadczenia, w obu miejscowościach, do czer- paka odłowiono podobną liczbę owadów, tj. 61 w Jarosławcu i $65 \mathrm{w}$ Pągowie. W drugim roku badań liczebność bzygowatych była znacznie większa w Pągowie (291 osobniki) w porównaniu do Jarosławca (233 osobniki). Najliczniej występującym gatunkiem Syrphidae był pospolity w Polsce, zoofagiczny Sphaerophoria scripta. Tylko w jednym przypadku, w Jarosławcu w 2013 roku najliczniejszym był Melanostoma mellinum, również drapieżny gatunek, który stanowił 28,8\% wszystkich odłowionych bzygów. Gatunek ten można uznać za dominujący również w Pągowie, ponieważ w 2012 roku stwierdzono $27,8 \%$ osobników tego gatunku oraz w 2013 16,8\%. Do gatunków dominujących, których liczebność przekroczyła $10 \%$ w wykazanym materiale entomologicznym w 2013 roku zaliczono również: saprofagiczny Syritta pipiens, 14,6\% w Jarosławcu i 21,2\% w Pągowie oraz zoofagiczny Episyrphus balteatus (2012 - 16,4\% w Jarosławcu, 2013 - 16,3\% również w Jarosławcu, 10,6\% w Pągowie. Liczebność pozostałych gatunków Syrphidae, nie przekroczyła 10\% liczebności zgrupowania.

Tabela 4. Skład gatunkowy i liczebność Syrphidae odłowionych do czerpaka entomologicznego w dwóch miejscowościach, w latach 2012-2013

Table 4. The species composition and number of Syrphidae caught with entomological net at two localities in 2012-2013

\begin{tabular}{l|c|c|c|c|c|c|c|c}
\hline \multirow{2}{*}{$\begin{array}{c}\text { Gatunek } \\
\text { Species }\end{array}$} & \multicolumn{4}{|c|}{2012} & \multicolumn{4}{c}{2013} \\
\cline { 2 - 11 } & \multicolumn{2}{|c|}{ Jarosławiec } & \multicolumn{2}{c|}{ Pągów } & \multicolumn{2}{c}{ Jarosławiec } & \multicolumn{2}{c}{ Pągów } \\
\cline { 2 - 11 } & $\mathrm{N}$ & {$[\%]$} & $\mathrm{N}$ & {$[\%]$} & $\mathrm{N}$ & {$[\%]$} & $\mathrm{N}$ & {$[\%]$} \\
\hline 1 & 2 & 3 & 4 & 5 & 6 & 7 & 8 & 9 \\
\hline Sphaerophoria scripta (L.) & 21 & 34,4 & 26 & 40,0 & 39 & 16,7 & 100 & 34,2 \\
\hline Melanostoma mellinum (L.) & 3 & 4,9 & 18 & 27,8 & 67 & 28,8 & 49 & 16,8 \\
\hline Syritta pipiens (L.) & 5 & 8,2 & 6 & 9,2 & 34 & 14,6 & 62 & 21,2 \\
\hline Episyrphus balteatus (Deg.) & 10 & 16,4 & 6 & 9,2 & 38 & 16,3 & 31 & 10,6 \\
\hline Eupeodes corollae (Fabr.) & 6 & 9,9 & 6 & 9,2 & 4 & 1,7 & 13 & 4,5 \\
\hline E. arbustorum (L.) & 1 & 1,6 & 2 & 3,0 & 16 & 6,9 & 7 & 2,4 \\
\hline Melanostoma scalare (Fabr.) & 3 & 4,9 & - & - & 3 & 1,3 & 8 & 2,7 \\
\hline Eumerus strigatus (Fall.) & - & - & - & - & 3 & 1,3 & 11 & 3,8 \\
\hline
\end{tabular}




\begin{tabular}{|c|c|c|c|c|c|c|c|c|}
\hline 1 & 2 & 3 & 4 & 5 & 6 & 7 & 8 & 9 \\
\hline Eristalis tenax (L.) & - & - & - & - & 6 & 2,7 & 4 & 1,4 \\
\hline Sphaerophoria rueppellii (Wied.) & 2 & 3,3 & - & - & 4 & 1,7 & 3 & 1,1 \\
\hline S. taeniata (Meig.) & 6 & 9,9 & - & - & 2 & 0,9 & - & - \\
\hline Syrphus vitripennis Meig. & 3 & 4,9 & - & - & 4 & 1,7 & - & - \\
\hline Eristalinus aeneus (Scop.) & - & - & - & - & 3 & 1,3 & 1 & 0,3 \\
\hline Tropidia scita (Harris) & - & - & - & - & 2 & 0,9 & - & - \\
\hline Syrphus ribesii (L.) & 1 & 1,6 & - & - & - & - & - & - \\
\hline Platycheirus peltatus (Meig.) & - & - & 1 & 1,6 & - & - & - & - \\
\hline Cheilosia pagana (Meig.) & - & - & - & - & 1 & 0,4 & - & - \\
\hline Eumerus sogdianus Stack. & - & - & - & - & 1 & 0,4 & - & - \\
\hline Helophilus hybridus Loew & - & - & - & - & 1 & 0,4 & 1 & 0,3 \\
\hline H. trivittatus (Fabr.) & - & - & - & - & 1 & 0,4 & - & - \\
\hline Pipizella viduata (L.) & - & - & - & - & 1 & 0,4 & - & - \\
\hline Platycheirus clypeatus (Meig.) & - & - & - & - & 1 & 0,4 & - & - \\
\hline P. fulviventris (Macq.) & - & - & - & - & 1 & 0,4 & - & - \\
\hline Sphaerophoria menthastri (L.) & - & - & - & - & - & - & 1 & 0,3 \\
\hline Scaeva pyrastri (L.) & - & - & - & - & 1 & 0,4 & - & - \\
\hline Suma - Total & 61 & 100,0 & 65 & 100,0 & 233 & 100,0 & 291 & 100,0 \\
\hline
\end{tabular}

$\mathrm{N}$ - liczebność - number

Łącznie, w ciągu dwóch lat badań w obu miejscowościach stwierdzono 26 gatunków bzygowatych odłowionych do czerpaka entomologicznego. W 2012 roku na mieszance w Jarosławcu wystąpiło 11 gatunków Syrphidae, natomiast w Pągowie - 7 (tab. 5). W Jarosławcu stwierdzono 5 gatunków, których nie wykazano w drugiej miejscowości oraz 1 gatunek w Pągowie, którego nie stwierdzono w Jarosławcu. W 2013 roku w odłowach czerpakiem w Jarosławcu stwierdzono 22 gatunki opisywanych muchówek, natomiast w Pągowie 15. Liczba wspólnych gatunków odłowionych w 2012 roku wynosiła 6, natomiast w 2013 13. W obu latach badań wskaźnik różnorodności gatunkowej Shannona-Wienera był wyższy w Jarosławcu niż w Pągowie (odpowiednio w 2012 roku 2,9 w Jarosławcu i 2,4 w Pagowie oraz w 2013 roku 3,1 w Jarosławcu i 2,8 w Pągowie). Podobieństwo składu gatunkowego badanych zgrupowań Syrphidae, wyrażone współczynnikiem Sørensena było niskie w obu latach, tj. w 2012 roku określono je na poziomie 0,66 i w 2013 roku na poziomie 0,63 .

Tabela 5. Charakterystyka ekologiczna zgrupowań Syrphidae odłowionych do czerpaka entomologicznego w dwóch miejscowościach, w latach 2012-2013

Table 5. Ecological characteristic of Syrphidae assemblages caught with entomological net at two localities in 2012-2013

\begin{tabular}{|c|c|c|c|c|}
\hline & \multicolumn{2}{|c|}{2012} & \multicolumn{2}{|c|}{2013} \\
\hline & Jarosławiec & Pągów & Jarosławiec & Pągów \\
\hline Suma Syrphidae - Total of Syrphidae & 61 & 65 & 233 & 291 \\
\hline Liczba gatunków - Number of species & 11 & 7 & 22 & 15 \\
\hline $\begin{array}{l}\text { Liczba gatunków wyłącznych } \\
\text { Number of separate species }\end{array}$ & 5 & 1 & 10 & 2 \\
\hline $\begin{array}{l}\text { Liczba gatunków wspólnych } \\
\text { Number of common species }\end{array}$ & \multicolumn{2}{|c|}{6} & \multicolumn{2}{|c|}{13} \\
\hline $\begin{array}{l}\text { Wskaźnik Shannona-Wienera } \\
\text { Shannon-Wiener index }\end{array}$ & 2,9 & 2,4 & 3,1 & 2,8 \\
\hline \multicolumn{5}{|c|}{ Współczynnik Sørensena - Sørensen’s index } \\
\hline Jarosławiec & - & 0,66 & - & 0,63 \\
\hline Pągów & 0,66 & - & 0,63 & - \\
\hline
\end{tabular}


Tabela 6. Skład gatunkowy i liczebność Syrphidae odłowionych do naczyń żółtych w dwóch miejscowościach, w latach 2012-2013

Table 6. The species composition and number of Syrphidae caught with yellow water traps at two localities in 2012-2013

\begin{tabular}{|c|c|c|c|c|c|c|c|c|}
\hline \multirow{3}{*}{$\begin{array}{l}\text { Gatunek } \\
\text { Species }\end{array}$} & \multicolumn{4}{|c|}{2012} & \multicolumn{4}{|c|}{2013} \\
\hline & \multicolumn{2}{|c|}{ Jarosławiec } & \multicolumn{2}{|c|}{ Pągów } & \multicolumn{2}{|c|}{ Jarosławiec } & \multicolumn{2}{|c|}{ Pągów } \\
\hline & $\mathrm{N}$ & {$[\%]$} & $\mathrm{N}$ & {$[\%]$} & $\mathrm{N}$ & {$[\%]$} & $\mathrm{N}$ & {$[\%]$} \\
\hline Episyrphus balteatus (Deg.) & 2 & 6,9 & 1 & 25,0 & 40 & 22,3 & 32 & 19,8 \\
\hline E. arbustorum (L.) & 12 & 41,4 & - & - & 42 & 23,3 & 1 & 0,6 \\
\hline Sphaerophoria scripta (L.) & - & - & 1 & 25,0 & 11 & 6,1 & 41 & 25,3 \\
\hline Eristalinus sepulchralis (L.) & 1 & 3,4 & - & - & 29 & 16,2 & 1 & 0,6 \\
\hline Eupeodes corollae (Fabr.) & 4 & 13,8 & 1 & 25,0 & 4 & 2,2 & 20 & 12,3 \\
\hline Syritta pipiens (L.) & - & - & - & - & 2 & 1,1 & 26 & 16,1 \\
\hline Eumerus strigatus (Fall.) & 1 & 3,4 & - & - & 13 & 7,2 & 5 & 3,0 \\
\hline Eristalis tenax (L.) & 6 & 20,8 & - & - & 8 & 4,4 & 4 & 2,5 \\
\hline Helophilus trivittatus (Fabr.) & - & - & - & - & 13 & 7,2 & 2 & 1,2 \\
\hline Sphaerophoria taeniata (Meig.) & - & - & - & - & - & - & 14 & 8,6 \\
\hline Melanostoma mellinum (L.) & - & - & - & - & 4 & 2,2 & 8 & 4,9 \\
\hline Helophilus hybridus Loew & - & - & - & - & 5 & 2,7 & 2 & 1,3 \\
\hline Eristalinus aeneus (Scop.) & - & - & - & - & 2 & 1,1 & 3 & 1,9 \\
\hline Helophilus pendulus (L.) & - & - & - & - & 1 & 0,6 & 3 & 1,9 \\
\hline Syrphus vitripennis Meig. & - & - & 1 & 25,0 & 2 & 1,1 & - & - \\
\hline Eristalis abusiva Coll. & 2 & 6,9 & - & - & - & - & - & - \\
\hline E. interrupta (Pod.) & 1 & 3,4 & - & - & - & - & - & - \\
\hline Cheilosia vernallis (Fal.) & - & - & - & - & 1 & 0,6 & - & - \\
\hline Melanostoma scalare (Fabr.) & - & - & - & - & 1 & 0,6 & - & - \\
\hline Syrphus torvus Osten-Sacken & - & - & - & - & 1 & 0,6 & - & - \\
\hline Xanthandrus comtus (Harris) & - & - & - & - & 1 & 0,6 & - & - \\
\hline Suma -Total & 29 & 100,0 & 4 & 100,0 & 180 & 100,0 & 162 & 100,0 \\
\hline
\end{tabular}

$\mathrm{N}$ - liczebność - number

Tabela 7. Charakterystyka ekologiczna zgrupowań Syrphidae odłowionych do naczyń żółtych w dwóch miejscowościach, w latach 2012-2013

Table 7. Ecological characteristic of Syrphidae assemblages caught with yellow water traps at two localities in 2012-2013

\begin{tabular}{|c|c|c|c|c|}
\hline & \multicolumn{2}{|c|}{2012} & \multicolumn{2}{|c|}{2013} \\
\hline & Jarosławiec & Pągów & Jarosławiec & Pągów \\
\hline Suma Syrphidae - Total of Syrphidae & 29 & 4 & 180 & 162 \\
\hline Liczba gatunków - Number of species & 8 & 4 & 18 & 14 \\
\hline $\begin{array}{l}\text { Liczba gatunków wyłącznych } \\
\text { Number of separate species }\end{array}$ & 6 & 2 & 5 & 1 \\
\hline $\begin{array}{l}\text { Liczba gatunków wspólnych } \\
\text { Number of common species }\end{array}$ & \multicolumn{2}{|c|}{2} & \multicolumn{2}{|c|}{13} \\
\hline $\begin{array}{l}\text { Wskaźnik Shannona-Wienera } \\
\text { Shannon-Wiener index }\end{array}$ & 2,4 & 2,1 & 3,2 & 2,9 \\
\hline \multicolumn{5}{|c|}{ Współczynnik Sørensena - Sørensen’s index } \\
\hline Jarosławiec & - & 0,33 & - & 0,63 \\
\hline Pągów & 0,33 & - & 0,63 & - \\
\hline
\end{tabular}

W przypadku odłowów Syrphidae do naczyń żółtych należy stwierdzić, że w obu latach muchówki te były liczniejsze w Jarosławcu niż w Pągowie (tab. 6). Łącznie w pierwszej z wymienionych miejscowości uzyskano 209 bzygów, w porównaniu do 166 osobników w drugiej miejscowości. Za najliczniejszy gatunek można uznać pospolitego w naszym kraju zoofaga $E$. balteatus, ponieważ łącznie $\mathrm{w}$ obu miejscowościach odnotowano 75 osobników tego gatunku. W poszczególnych latach i miejscowościach dominowały jednak inne gatunki. 
W 2012 roku w Jarosławcu, najliczniejszym był saprofagiczny Eristalis arbustorum (41,4\%). W tym samym roku w Pągowie, odłowiono do naczyń żółtych tylko pojedyncze osobniki Syrphidae, należące do czterech gatunków. W 2013 roku w Jarosławcu również dominował E. arbustorum (23,3\%), natomiast w Pągowie S. scripta $25,3 \%$.

Łącznie w obydwu latach badań i obu miejscowościach wykazano 21 gatunków Syrphidae odłowionych do naczyń żółtych. W 2012 roku w przypadku Syrphidae w Jarosławcu uzyskano 8 gatunków, natomiast w Pągowie - 4 . W 2013 roku liczba oznaczonych Syrphidae wynosiła odpowiednio 18 gatunków w pierwszej z badanych miejscowości i 14 gatunków w drugiej (tab. 7). W pierwszym roku badań w Jarosławcu stwierdzono 6 gatunków badanych owadów, natomiast w Pągowie 2 gatunki, które były wyłącznymi dla zgrupowań Syrphidae w każdej z miejscowości. Jednocześnie w 2012 roku oznaczono zaledwie 2 gatunki wspólne dla obu miejscowości. W 2013 roku wykazano 5 gatunków wyłącznych w zgrupowaniach w Jarosławcu i 1 w Pągowie, a liczba gatunków wspólnych wynosiła 13. Wartości wskaźnika różnorodności gatunkowej Shannona-Wienera dla porównywanych zgrupowań Syrphidae w obu latach były wyższe w Jarosławcu niż w Pągowie. Jakościowe podobieństwo zgrupowań bzygowatych wyrażone współczynnikiem Sørensena, określono w 2012 roku na niskim poziomie, tj. 0,33. Wyższe było w 2013 roku i wyniosło 0,63 .

Głównym celem pracy było zbadanie możliwości przywabiania chrząszczy z rodziny Carabidae oraz muchówek należących do Syrphidae w okolice pól uprawnych przez odpowiednio skomponowaną mieszankę kwitnących roślin, w dwóch miejscowościach zachodniej części Polski. Zdecydowaną większość wybranych do porównania grup owadów stanowią gatunki pożyteczne (Thiele 1977; Sunderland i wsp. 2001). Gatunki oznaczone w badaniach również prowadzą głównie zoofagiczny tryb życia. Zaproponowana mieszanka kwitła od końca maja do końca września przywabiając liczne owady pożyteczne. Różne gatunki kwitnących roślin $\mathrm{w}$ rozmaitym stopniu przywabiają owady pożyteczne (Heitzmann i wsp. 1990). Spośród komponentów mieszanki rosnącej zarówno w Pągowie, jak i w Jarosławcu, najatrakcyjniejszą dla entomofauny pożytecznej była facelia błękitna, który to gatunek kwitł długo i pokrywał największą powierzchnię. Schmutterer i Gaudchau (1986) stwierdzili, że facelia jest bardzo atrakcyjna dla bzygowatych. Harwood i wsp. (1992) sugerują, że tak urozmaicone florystycznie powierzchnie zwiększają liczebność Syrphidae w agrocenozie. Potwierdziły to badania prowadzone przez Hureja i wsp. (1998) oraz Twardowskiego (2002). Mieszanka kwitnących roślin jest atrakcyjnym stanowiskiem również dla chrząszczy $\mathrm{z}$ rodziny Carabidae, które prowadzą naziemny tryb życia. Dla nich mieszanka jest nie tylko miejscem zdobywania pokarmu, ale też siedliskiem ostojowym o specyficznym mikroklimacie, gdzie znajdują schronienie i odpowiednie miejsce na zimowanie. Uzyskane przez Twardowskiego i wsp. (2006) wyniki wskazują, że większa liczebność oraz różnorodność gatunkowa roślin porastających pasy mieszanki roślin istotnie zwiększają liczebność i różnorodność gatunkową biegaczowatych. Badania przeprowadzone w Pągowie i w Jarosławcu na mieszance kwitnących roślin potwierdzają tezę, że zwiększona różnorodność roślinna w agrocenozach wpływa korzystnie na zwiększenie liczebności drapieżnych owadów, które w agroekosystemach mogą być pomocne w regulacji liczebności organizmów szkodliwych.

\section{Wnioski / Conclusions}

1. Spośród chrząszczy $\mathrm{z}$ rodziny Carabidae, zdecydowanym dominantem $\mathrm{w}$ obu miejscowościach i obu latach, był $H$. rufipes. W Pągowie do licznych należały również $P$. melanarius i $B$. quadrimaculatum, natomiast w Jarosławcu P. lepidus i D. halensis.

2. W przypadku muchówek $\mathrm{z}$ rodziny Syrphidae odławianych przy pomocy czerpaka entomologicznego, dominujące $\mathrm{w}$ obu miejscowościach były gatunki: S. scripta, M. mellinum, S. pipiens i E. balteatus. Do naczyń żółtych liczniej odławiany był E. balteatus, a także E. arbustorum (w Jarosławcu) i S. scripta (w Pągowie).

3. W charakterystyce ekologicznej zgrupowań biegaczowatych oraz bzygowatych wykazano znaczne różnice między obiema porównywanymi miejscowościami, zwłaszcza pod względem jakościowym.

\section{Literatura / References}

Altieri M.A. 1999. The ecological role of biodiversity in agroecosystems. Agriculture, Ecosystems and Environment 74: 19-31.

Altieri M.A., Letourneau D.K. 1982. Vegetation management and biological control in agroecosystems. Crop Protection 1 (4): 405-430. Balmer O., Pfiffner L., Schied J., Willareth M., Leimgruber A., Luka H., Traugott M. 2013. Noncrop Flowering Plants Restore TopDown Herbivore Control in Agricultural Fields. Ecology and Evolution. John Wiley \& Sons Ltd.: 1-13.

Carreck N.L., Williams I.H. 1997. Observations on two commercial flower mixtures as food sources for benefcial insects in the UK. Journal of Agricultural Science 128: 397-403.

Ditner N., Balmer O., Beck J., Blick T., Nagel P., Luka H. 2013. Effects of experimentally planting non-crop flowers into cabbage fields on the abundance and diversity of predators. Biodiversity and Conservation 22: 1049-1061.

Gurr G.M., Wratten S.D., Altieri M.A. 2004. Ecological Engineering for Pest Management: Advances in Habitat Manipulation for Arthropods. CSIRO Publishing, 225 pp.

Harwood R.W.J., Wratten S.D., Nowakowski M. 1992. The effect of managed field margins on hoverfly (Diptera: Syrphidae) distribution and within-field abundance. The BCPC Conference - Pests and Diseases: 1033-1037. 
Heitzmann A., Lys J.A., Netwig W. 1990. Ecological compensation through strip-management: botanical and zoological aspects. Schweizerische Landwirtschaftliche Forschung 29 (4): 331-337.

Hurej M., Król J., Twardowski J. 1998. Attraction of aphid predators by cultivated and weedy strips. Aphids and Other Homopterous Insects 6: 117-124.

Schmutterer H., Gaudchau M. 1986. Anlockung von Syrphiden durch kunstlich als Ersatz für Unkräter in Winterweizenbeständen angesäte Phacelie (Phacelia tanacetifolia) und Auswirkung auf Getreideblattläusse. DFG, Forschungsbericht: Herbizide II. VHC Verlagsges, Weinheim: 115-128.

Sunderland J.P., Sullivan M.S., Poppy G.M. 2001. Distribution and abundance of aphidophagous hoverflis (Diptera: Syrphidae) in wildflower patches and field margin habitats. Agricultural and Forest Entomology 3: 57-64.

Thiele H. 1977. Carabid Beetles in Their Environments. Springer-Verlag, 369 pp.

Twardowski J. 2002. Wpływ zwiększonego zróżnicowania roślinnego w agrocenozach na populacje fitofagów i ich wrogów naturalnych. Rozprawa doktorska. Uniwersytet Przyrodniczy we Wrocławiu, 143 ss.

Twardowski J., Hurej M., Jaworska T. 2006. An effect of strip-management on carabid beetles (Col., Carabidae) in sugar beet crop. Journal of Plant Protection Research 46 (1): 61-71. 